determine the right number of leeches in each case. When it is a question of once applying four or five leeches to the womb. one should be more guided by the inflammatory nature of the complaint than by the state of the patient's strength. I have sometimes long hesitated to deprive weak and anæmic patients of even the smallest amount of blood; but other measures failing, I have done so with the best effects. The success of a first may lead to the trial of a second application, after some interval has elapsed. In pelvic peritonitis, which frequently follows morbid ovulation and uterine disease-in acute ovaritis, supposing the examination be not too painful, I agree with Aran and Scanzoni, that it is better to apply leeches to the womb, or, better still, to the vaginal cul-de-sac.

The vascular system of the ovario uterine organs is often permanently and actively congested, either from the menstrual molimen having been unsatisfied by its accustomed secretion, or by the retention of the secreted menstrual flow. In such cases, a few leeches before the menstrual period will often set things right. In some cases amenorrhoa or metrorrhagia depends on congestion of the pelvic vessels, (and this may be inferred from the varicose condition of the veins of the vagina and labia, and then leeching the vaginal cul-de-sac is of great service. Scanzoni states that metrorrhagia which resisted the usual treatment, suddenly ceased on the application of a few leeches to the womb. I have no experience of the practice, but it deserves trial, as the quantity of blood taken away by the leeches is insignificant when compared to that otherwise lost. When fibrous tumours cause menorrhagia, it is likewise good to apply leeches to the womb before the menstrual periods.

In hæmatocele or hæmatic collections of blood in the pelvis, I agree with Dr. Bernutz, that the re absorption of the effused blood is greatly promoted by two or three applications of leeches at three or four days' interval, and by another application at the first sign of the ensuing menstrual period. In this case it is better to apply the leeches to any easily-attainable and bulging portion of the vagina.

Counter-indications. - I consider the application of leeches to the womb as counter-indicated by very acute inflammation, and when the vagina is inflamed. Whenever a digital examination is very painful, it is to be feared that the pain and fatigue of the operation will considerably detract from the advantages to be otherwise expected from the application of leeches. By applying leeches to the inner part of the thighs, and the assiduous use of emollient injections to the vagina, inflammation will generally be soon sufficiently reduced to permit the application of leeches to the womb. Leeches should not be applied in cancerous or syphilitic affections of the womb, for fear each leechbite should become an ulcer. For a similar reason, leeches should not be applied to the womb when its inflammation is characterized by the production of diphtherial membranes. In a case I am now attending, the patient had previously consulted another practitioner, who, unacquainted with this uncommon variety of disease, applied leeches to the womb. Each leechbite became an ulcer, covered with a diphtheritic membrane, and the complaint was thus greatly increased by the injudicious application of a good remedy.

Grosvenor-street, Jan. 1861.

\section{INFANT ALIMENTATION;}

OR,

\section{ARTIFICIAL FEEDING, AS A SUBSTITUTE FOR BREAST-MILK, CONSIDERED IN ITS PHYSICAL} AND SOCIAL ASPECTS.

\section{BX M. A. BAINES.}

Str,-At the Bradford meeting of the Social Science Association last year, I had the pleasure of contributing to the Public Health Department a paper on the "Practice of Hiring Wet-nurses," showing the numerous evils which are involved in that system; my object being to prove that the cases are very rare in which a wet-nurse is really needed, and that the abuse of the practice must necessarily lead to very serious consequences, not only to individuals, but to the community at large.

This idea being accepted, a question naturally arises as to the best substitute for breast-milk in the case of hand-reared children. To that question I shall attempt to give a satisfactory answer. A few preliminary observations will be necessary.
In a paper presented to the Sanitary Section of the International Statistical Congress, which held its session in London this year, I pointed out the want of accurate information on the subject of Wet-nursing, and suggested a simple method by which figures might be obtained in order to show the extent to which the custom prevails in this country; such machinery being set at work, an important means will be available for collecting very interesting and valuable information on subjects of a kindred nature.

The practice of employing wet-nurses cannot be considered and inquired into without revealing many startling facts which are counected with the system. Amongst its most disastrous results may be regarded the fate of the wet nurse's child, which is in most cases put out to dry-nurse, falls into ignoraut or unprincipled hands, and, as a consequence, too often meets with premature death. Space does not permit me to enter into a consideration of all the moral evils of such a system, but it is enough to speak of the indifference to infant life which is thus fostered, and which is evidenced by the fact that a mother is induced, and too readily yields, to the temptation to sell her child's life for the temporary iudulgence in ease and gain. $\mathrm{Oh}$ ! let those who have any influence in this matter pause ere they help to sever those holiest and jurest of earthly ties which Nature has intended, with wise purpose, should exist between a mother and her child.

In the paper on the "Statistics of Wet-nursing," I alluded to one or two subjects which, although not coming immediately under the inquiry therein indicated, nevertheless present some significant features in relation to it, and for that reason deserve some attention here. I refer to the large number of infants said to be annually "still-born" in this country, and also to the system carried on with regard to children whose names are entered on the books of burial clubs.

With respect to the first-named subject, Lord Shaftesbury, in his address at Liverpool on Public Health, made the following statement-that no less than 60,000 ' still-born' children are produced in this country every year;" adding, that " it is a portentous fact, which demands the most solemn investi. gation." *

I am not aware what idea the noble President connected with the fact to which he called attention with so much earnestness; probably his Lordship had in his view the unsanitary condition of things which it discloses. Certainly that is a very grave matter-one which may with advantage be inquired into. Why (it may be asked) should so large a number of individuals-so larye a portion of the female population-fail to fulfil the natural laws of their being, and thus contribute to such an abnormal and astounding fact as that indicated in the high rate of the "still-born"? Again, how is it that so many mothers who give birth to living children are unable to afford them the maternal nourishment which is their birthright, thus depriving their offspring of the best chances of maintaining existence?

The latter subject was alluded to by Mr. E. Chadwick, at the International Statistical Congress. His remarks referred only to what takes place in Manchester; but it would be worth while to collect information on these points as regards every town and district in the kingdom.

These inquiries are serious enough in a sanitary point of view; but I fear they present another side still more painful and portentous: I allude to the criminal aspect, especially as regards the 60,000 " still-born." It is probable that more than half of that number ought not to have been so recorded. And to check the evil in future, the law must be brought to bear upon the system to which the evil is due. At present the great facilities afforded for the disposal of " still-born" children offer free inducements to infanticide, which crime is on the in. crease, and is, no doubt, perpetrated wholesale in some parishes and districts. Dr. Bachhoffner, the Registrar for Marylebone, has lately instituted inquiries into this matter in the district over which he presides. Some startling facts bave been elicited, and the investigation is still being prosecuted; but from what has already transpired, there can be no doubt that some restrictive clauses are urgently needed in the Burial Act with reference to the disposal of infants said to be "still-born," such subjects having been hitherto enclosed in the coffus of * It was stated by Dr. Ballard, at the Statistical Congress, that "England is the only country in which there are no official returns as to "still-born' children." But although no complete records are at present furnished, (because none have been authoritatively required,) there must be sources from which such information can be obtained-as, for instance, the books of burial societies. The secretaries of such societies might be instructed to collect facts under this head; also registrars and medi, al efficers of health, especially in cistricts containing vorkhouses, should make "returns" of a similar kind. It is most desirable that such figures and facts should be systematized and
utilized under official authority. 
adults without the payment of regular fees, and without requiring the production of a medical certificate.

It will be at once obvious how full of meaning are the foregoing facts in connexion with the subject of this paper, when I su grest that it wonld be interesting and instructive to know how many of the mothers of "st.ll-born" children had, previously to the birth, decided upon taking up the rocation of wet nurse. And, again, how many of the infants whose names have been entered on the bools of burial societies, and who die prematurely, are children who have been put ont to diy vurse to enable the mothers to take places as "wet nurses."

Althongh it was my intention to treat the subject of this letter surictly in its sanitary aspects, and to aldress my remarks more particularly to medieal men, I have been almost unconsciously led into the consideration of other social ques. tions of equal importance; and I have no reason to regret having entered npon the more extended view of the subject, because, in the first place, they are questions which must be interesting to all social reformers; and secondly, I think that those (I refer now to members of the medical professious) who would desire to aid the special cause we are about to consider would do well to regard it, not only in its physioal aspects, not only from what is termed a "medical point of view," but in reference to its moral and social relations and influences.

In a paper which was read in London last February before a medical audience, I advocated the use of vegetable or fariı.a. ceous substances, in combination with cows' milk, as a proper food for infants, from the earliest period of existence.

Hand-feeding has got into disrepute because it is in general so unsuccessful in its results; and as "eonvulsions" and other disorders, terminating fatally in childhood, are often traced, when properly in restigated, to the improper ase of farinaceots substances, a prejudice has arisen agairst that kind of food, and it is interdicted as injurious by medical practitioners; consequently the public, taking alarm without reason, look upon farinaceous food as little short of poison in its pernicions effects upon the infant constitution. This is a foolish and fatal error! Not less absurd, though far less misehievous, would it be to prohilit bathing altogether, because some reckless persons, ignorant of the art of swimming, plunge into the water, and are drowned. I am strongly convineed that it is not so much the kind of food that kills as the ignorant manner in which food given to infants is prepared and administered.

There are two extremes prevalent, both equally to be deprecated, -namely, the excessive use of farinaceons food, and its entire probibition. I consider that to depend wholly upou animal milk is a most disastrous practice, and in many cases induces disorders which, if they do not always terminate fatally, set up a condition which predisposes to various ailments in more advanced childhood, and even in later periods of life. These disorders are rarely referred to the true eause, but are described as "constitutional," "developmental," and so on; when the truth is that the system, being deprivel of the elements in its food necessary for grow th and development, suffers from difective nutrition, and consequently his not power to carry on its processes in a nataral and satisfactory manner. It would be curious to know how many of the dexths returned in the registrars' reports under "Want of breastmilk," are those of children who were attempted to be reared (but in effect were starved) upon animal milk alone; I fancy the numbers wonld quite equal those of the children who die in convulsions from "over-feeding."

I cannot now enter upon the chemical and physiological arguments which I am prepared to advance in favour of my theory; I will only state that I believe Chemistry (as far as it is known to us at present) cannot be trusted in this matter. What 1 mean is this: that although we may learn by chemical analysis that cows' milk approaches naarly to human milk in its constituents and their relative proportions, that fact affords no satisfactory proof that animal milk contains in its elements or component parts the necessary qualities or properties suit. able for the nutrition of an intant, so as to renler that milk a safe substitute for breast-milk without the addition of other substances; indeed, experience tells us quite the ruserse. And as to the physiological facts which have been brought forward by opponents to my views, I have explained at sume length in another place, * that I interpret those same facts in a manner to favour my argument. [Comparative anatomy does not teach me that because vegetable food is inlicated as suitable for digestion in the case of the young of the animal creation, therefore the anatomical construction of the human stomach shows the same food to be unsuitable with regrard to the human in * The Comparutive Properties of Human and Amimal Milks, de. London: Churchill. fant.] Chemical analysis may aid us in discovering truth, but I have said that it must not be trusted entirely; experience will prove a better teacher in such matters; for out of wellobserved facts we may draw practical conclusions, and trace them with something like certainty to their respective causes. I am intuce? on this account to suggest (and I do so with much deference), that unless any medical practitioners can bring their expcrience to bear upon this question, they will reserve their remarks; for although $I$ am anxious to induce discussion on the subject of this letter, I should be sorry for the cause to be prejudiced by the mere repetition of old objections, having no better authority than that derived from the rlogmas which belong to routine prastice, and based upon no solid nor tenable foundation.

If any medical man would undertake to conduct a series of experiments as to the value of farinaceous foods in the cases of children who may be depending entirely upon artificial feeding, such a piactioal experimentalist would perform a signal service to mankind. Let a fair trial be made under the direction and observation of tlie medical attendant, and let him report the result to the profession and the public through the medical journals, whese columns are always open to contributions which are calculated to benefit the cause of science and humanity. *

Brighton, Dec. 1860.

\section{a) allitor}

OF TUE PRACTICE OF

\section{MEDICINE AND SURGERY IN THE}

\section{HOSPITALS OF LONDON.}

Nulla est alia pro certo noscendi via, hisi quam plurimas et morbơtum et dissectionum historias, tam aliorum proprias, collectas habere $\epsilon$ inter se com purare-MorgagN. De Sed. et Caus. diforb., lib, 14. Procmium.

\section{UNIVERSITY COLLEGE HOSPITAL.}

COLLOID DISEASE OF TIE RIGHT, AND MULTILOCUEAR DISEASE OF THE EEFT, OVARIES; OVARTOTOMY; FATAL RESULT.

\section{(Under the eare- of Mr. ERICHSEN.)}

Tre subject of curing ovarian disease by extirpation, or otherwise, has of late years especially occupied the attention of British practitioners, and a large number of cases are now on record in which some one or other of the various means of relief have proved successful. Constitutional treatment, tapping, tâpping conjoined with pressure, injection, and extirpation, have in turns been tried-some as merely palliative, and others again as curative. Our pages have afforded examples of all these; and experience has amply proved that medicine alone will do nothing towards the cure or the absorption of an ovarian cyst. Tapping afforis relief for a time, and in some instances it has prolonged life for a considerable number of years. This process conjoined with firm pressure has been successful in the hands of Mr. Baker Brown, Mr. May, of Tottenham, and perhaps others: three examples under the first-named surgeon were recorded in a recent number of this journal (vol. ii, 1860, p. 435); and a fourth was announced by Mr. May (ibid., p. 565). This plan is worthy of a more extended trial in those cases wherein the patient is not too old, and where there is but a single cyst and the general health is good. There is this drawback, however, that in the event of success for the time being, any secondary cysts that have hitherto been quiescent may become developed when the * Another consideration in favour of my suggestion is, that ill-nourished children-those who are improperly fed, either by an excess of fcod or unsuitable diet-more readily fall a sacrifice to epidemies; whilst those subjects whose blood is kept in a pure sta'e by wholesome food, have the power of resisting the influences which strike down the feeble frames $r y$ hundreds. I believe that diarrhrea is oftener induced by wrong diet than by any at mospheric or any other local eauses; at any rate, at tacks are much more serious and fatal in enses whero inattention to diet prevails. If this be true as regards adults,
the fact is still more foreible with reference to children. 